\title{
Prisoners of Freedom
}




\section{CALIFORNIA SERIES IN PUBLIC ANTHROPOLOGY}

The California Series in Public Anthropology emphasizes the anthropologist's role as an engaged intellectual. It continues anthropology's commitment to being an ethnographic witness, to describing, in human terms, how life is lived beyond the borders of many readers' experiences. But it also adds a commitment, through ethnography, to reframing the terms of public debate - transforming received, accepted understandings of social issues with new insights, new framings.

Series Editor: Robert Borofsky (Hawaii Pacific University)

Contributing Editors: Philippe Bourgois (UC San Francisco), Paul Farmer (Partners in Health), Rayna Rapp (New York University), and Nancy Scheper-Hughes (UC Berkeley)

University of California Press Editor: Naomi Schneider

I. Twice Dead: Organ Transplants and the Reinvention of Death, by Margaret Lock

2. Birthing the Nation: Strategies of Palestinian Women in Israel, by Rhoda Ann Kanaaneh (with a foreword by Hanan Ashrawi)

3. Annibilating Difference: The Anthropology of Genocide, edited by Alexander Laban Hinton (with a foreword by Kenneth Roth)

4. Pathologies of Power: Health, Human Rights, and the New War on the Poor, by Paul Farmer (with a foreword by Amartya Sen)

5. Buddha Is Hiding: Refugees, Citizenship, the New America, by Aihwa Ong

6. Chechnya: Life in a War-Torn Society, by Valery Tishkov (with a foreword by Mikhail S. Gorbachev)

7. Total Confinement: Madness and Reason in the Maximum Security Prison, by Lorna A. Rhodes

8. Paradise in Ashes: A Guatemalan Journey of Courage, Terror, and Hope, by Beatriz Manz (with a foreword by Aryeh Neier)

9. Laughter Out of Place: Race, Class, Violence, and Sexuality in a Rio Shantytown, by Donna M. Goldstein

IO. Shadows of War: Violence, Power, and International Profiteering in the Twenty-First Century, by Carolyn Nordstrom

II. Why Did They Kill? Cambodia in the Shadow of Genocide, by Alexander Laban Hinton (with a foreword by Robert Jay Lifton)

I2. Yanomani: The Fierce Controversy and What We Can Learn from It, by Robert Borofsky

13. Why America's Top Pundits Are Wrong: Anthropologists Talk Back, edited by Catherine Besteman and Hugh Gusterson

I4. Prisoners of Freedom: Human Rights and the African Poor, by Harri Englund 


\section{Prisoners of Freedom}

Human Rights and the African Poor

\section{Harri Englund}

— UNIVERSITY OF CALIFORNIA PRESS Berkeley / Los Angeles / London 
University of California Press, one of the most distinguished university presses in the United States, enriches lives around the world by advancing scholarship in the humanities, social sciences, and natural sciences. Its activities are supported by the UC Press Foundation and by philanthropic contributions from individuals and institutions. For more information, visit www.ucpress.edu.

University of California Press

Berkeley and Los Angeles, California

University of California Press, Ltd.

London, England

(C) 2006 by The Regents of the University of California

Library of Congress Cataloging-in-Publication Data

Englund, Harri.

Prisoners of freedom : human rights and the African poor / Harri Englund.

p. $\quad \mathrm{cm} .-$ (California series in public anthropology : I4)

Includes bibliographical references and index.

ISBN-I3 978-O-52O-24923-3 (cloth : alk. paper), ISBN-IO 0-52O-24923-2 (cloth : alk. paper)

ISBN-I3 978-O-520-24924-O (pbk. : alk. paper), ISBN-IO 0-520-24924-O (pbk. : alk. paper)

I. Human rights - Malawi. 2. Poverty - Malawi. 3. Ethnology Malawi. 4. Democracy - Malawi. I. Title. II. Series.

JC599.M3E54 2006

$323.096897-\mathrm{dc} 22$

2005032837

Manufactured in the United States of America

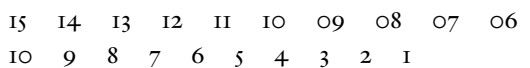

This book is printed on New Leaf EcoBook 50 , a 100\% recycled fiber of which $50 \%$ is de-inked post-consumer waste, processed chlorinefree. EcoBook 50 is acid-free and meets the minimum requirements of ANSI/ASTM D5634-OI (Permanence of Paper). 
For Guðrún 
This page intentionally left blank 